\title{
The Creative Process of Indonesian Muslim Novelists
}

\author{
$1^{\text {st }} \mathrm{R}$ Rachmy Diana* \\ Department of Psychology \\ State Islamic University Sunan Kalijaga \\ Yogyakarta, Indonesia \\ raden.diana@uin-suka.ac.id
}

\author{
$2^{\text {nd }}$ Fuad Nashori \\ Department of Psychology \\ Universitas Islam Indonesia \\ Yogyakarta, Indonesia \\ fuadnashori@uii.ac.id
}

\author{
$3^{\text {rd }}$ H. Adam Anshori \\ Department of English Education \\ Universitas Islam Indonesia \\ Yogyakarta, Indonesia \\ adam.anshori@uii.ac.id
}

\begin{abstract}
The aim of this research is to explore the creative process of Indonesian Muslim novelists. The method used in this research is qualitative method; specifically, in this context is descriptive-explorative method. The questions asked to the research participants were conducted by using in-depth interview. The subjects were active Muslim novelists whose have produced more than 5 novels related to Islam or having Islamic nuances. The results of this study show that creative ideas were obtained by: (i) awareness of God as a source of ideas, (ii) the activity of reading and watching, (iii) observing human behaviors and natural phenomena, (iv) contemplating, (v) creating an atmosphere that support the writing of the novel, (vi) realizing that the novel will be accountable to God, (vii) maintaining good relationship with God through worship, (viii) maintaining good relationship with fellow human beings, (ix) writing as part of sharing, and (x) writing as part of $d a^{\prime}$ wah (spreading Islamic values).
\end{abstract}

Keywords-creative process, thinking, Indonesian Muslim novelist

\section{INTRODUCTION}

One problem that is faced by every writer, thinker, and novelists in any field is to get new ideas. They told stories about how to get the inspiration. Nashori and Mucharam [1] report that one way to get creative ideas is to stimulate our thinking through physical environment, cognition-emotion, or social environment. Physical environment can provide stimulation by exposing oneself to new situation or certain place. Oppezzo and Schwartz [2] found that walking can stimulate and increase creativity. Nashori and Mucharam [1] illustrate cognitive stimulation can be in the form of problem-solving exercises that force them to think creatively. Emotional stimulation provide deep experience to be more empathetic to other people's problem. Social stimulation is a situation where discussion takes place and various opinions on one topic emerge. Through the discussion of contradicting opinions, one idea will be sharpening and more solid.

In psychological perspective there are two phases of a creative process, namely the incubation period. It is when a person is having problem that is not yet solved, but the thought of it is there. After some time of incubation period usually follows a point of insight, when creative ideas surface $[3,4,5]$. This phenomenon has been described quite thoroughly by Eneste [6] covering the experiences of Indonesian novelists: Sutan Takdir Alisyahbana, A.A. Navis, Ajip Rosidi, Putu Wijaya, Trisnoyuwono, N.H. Dini, Toeti Heraty, Subagjo Sastrowardoyo, Wildan Yatim, Budi Farma, Arswendo Atmowiloto, and among others.
It is interesting to understand and analyze the uniqueness of Muslims creative experience, since they usually are people who have strong faith. The case is not the same with the western idea of creativity. As mentioned by Csikszentmihalyi [7]), creative process is a process of enjoyment that your mind is focused on "here and now" experiences. It is quite salient that hedonism has influenced how westerners define creativity. Muslims have different view of their life compared to the westerners.. It is interesting to see the values believed by the muslims writer influence their creative activity as well.

Previous research by Nashori [8] and Lismarwan and Nashori [9] found that the creative process of Muslim writers and Muslim calligraphers involved spirituality. Nashori (2004) specifically found that the creative process of the writer (in this case the author of a scientific book) involves a focus on the area in which he is engaged, associating with others, enjoying the activities undertaken, worship, and good morals. Meanwhile, Lismarwan and Nashori [9]. found that the creative process of painting calligraphy involves associating with reality, a supportive mood, strong interest in themes, deepening of the theme of painting, technical ability, moved by divine awareness, and performing religious activities in the creation process. The research results above emphasize that the process of writing novels also involves belief in God, worship, and noble morals.

In order to reveal this uniqueness, the research questions are: what do Muslim novelists experience during their creative process? What kind of psycho-spiritual behavior do they have in order to get original ideas?

\section{METHODS}

This study applies qualitative method that is aimed to collect holistic data from the respondents. The respondents are six Indonesian Muslim novelists who at least had published five titles of novel book. Seven respondents were interviewed using in-depth interview technique. Through this approach, it is expected that a comprehensive and rich description of the phenomenon will be obtained.

The verbatim of the interview was analyzed and categorized into some domain that represent the process of the creative activities. It starts from each domain that emerges from the first interview, and then followed by the second interview to elaborate the specific domain. If the respondent mentions conflicting statement, then another interview is conducted to clarify [10]. 
The procedure of this research are as follows. First: searching for names of Indonesian novelists who have published at least five novels as respondents. If the respondent is willing to become participant for this research, they are also asked to provide recommendations for names of other novelists in order to become the next respondent. Second: contact them and ask their willingness to answer questions in written form. Third: sending a number of questions and analyze some explanation by respondents by doing probing. The researcher asks the respondent to clarify the answers, specify the answers, or add their answers. Fourth: further interviews are conducted to uncover various issues that need to be further studied. Fifth: after completing the interview, a domain analysis is carried out to find out the domains covered by the respondent's creative process. Sixth: checking all elements in the domain obtained from the contrast interviews. This step is done when there are conflicting statements. Seventh: write the final text in accordance to the guidelines for writing scientific papers.

\section{FINDINGS}

The result of the study showed that the creative process were obtained by: (i) awareness of God as a source of ideas, (ii) the activity of reading and watching activities, (iii) observing various human behaviors and natural phenomena, (iv) contemplating, (v) creating an atmosphere that support the writing of the novel, (vi) realizing that the novel will be accountable to God, (vii) maintaining good relationship with God through worship, (viii) maintaining good relationship with fellow human beings, (ix) writing as part of sharing, and (x) writing as part of dakwah (spreading Islamic values).

\section{The first theme: Awareness of God as a source of ideas}

Muslim novelists have awareness that the novels and other writings they produce are all devoted to Allah the Creator of man and the universe.

I have faith that all knowledge comes from Allah. Without his permission, it would be impossible for me to easily get ideas in writing novels (Respondent 1, ES)

Allah SWT really helped me in terms of motivation, which is how Allah SWT gave me ideas, motivation, and health ... (Respondent 2, LM)

Inequalities that arose around those related to monotheism, clearly led to an abundance of ideas (Respondent 3, RD)

I will not have anything if Allah is not pleased with my ownership. So, yes, I think when I believe God makes it easy and helpful, then all the processes in writing will be easy and helpful (Respondent 4, FR)

\section{The second theme: the activity of Reading and watching}

Muslim novelists try to get the idea of writing novels through reading books and trusted sources related to the topic of their novel. They also watch movies, and other sources. This step is taken with the awareness that reading will enrich the content and contextof their novels.

In fact, every time I study the interpretation of the Qur'an or the Hadith, subhanallah, it turns out that the vastness of Allah's knowledge can be explored. And I'm still nothing. Then, Allah's knowledge becomes the main foundation for creative writing. Allah's knowledge is very inspiring and very broad (Respondent 5, NS)
I can get ideas from books that I read, films that I watch (Respondent 4, FR)

Technically writing a novel is easier when I have a lot of references. Usually before writing a novel, I will seek references first, through books, similar novels, movies ... (Responent 2, LM)

I am not really sure how to come up with an idea to write. . Sometimes even while doing nothing, ideas for writing novels suddenly appear. But, from my experience, reading books and watching movies do help me in getting ideas to write (Respondent 6, MF)

\section{The third theme: Observing various human behaviors} and natural phenomena

Muslim novelists show high sensitivity to human behaviors and natural phenomena that surround them. These events are like springs that never stop flowing which can be used as writing novelsThe most frequent idea I get from observing social phenomena that exist (Respondent 1, ES)

I often get the idea of writing novels through people or the environment I observe (Respondent 4, FR)

Reading is not only in the form of reading, but also reading around (environment and nature). If we are sensitive, surely we will not run out of ideas. Reading then raises anxiety if something is not in accordance with the heart, for example the impact of humans who do not protect nature, the impact of the internet on children's behavior, and so on. It is the unrest that then raises the idea of how we convey to the reader (Respondent $3, R D$ )

The idea will arise if there is something out of line (both human and natural environment) that is not in accordance with manners / character (Respondnet $3, R D$ )

For me, fiction, one of which is a novel, is a processed imagination taken from a true story. Everything is around us. Life lessons. It's like an endless spring (Respondent 5, NS)

\section{The fourth theme: Contemplating}

Muslim novelists realize that one way to obtain and mature ideas is to learn and contemplate on various events in the past. Ideas arises during the sleeping time as part of the past experience.I get ideas easily from contemplation or when recalling past experiences (Evy Sofia)

Eyes to view. Ears to record. Brain to analyze. And heart to manage. Thought freed to call creative ideas (Nashita)

\section{I sometimes get ideas while sleeping (Fakhrisina)}

\section{The fifth theme: creating an atmosphere that supports in writing the novel}

Muslim novelists realize that they need an environment that is stimulating andeasy for them to write their ideas for writing. They create an atmosphere that supports it.

I need certain situations that make it easy for me to write and stimulate me to get inspired. Normally, I would arrange the place where I would write, for example a room or living room, with a quiet atmosphere so that I could focus on the story in my novel. I am not used to writing in cafes in a crowded atmosphere, as well as writing in musical accompaniment. Writing in a quiet and quiet atmosphere is always able to make me find inspiration and focus in the story. (Laili Muthmainnah) 
The sixth theme: Realizing that the novel will be accountable to God

Muslim novelists realize that everything written down must be justified before God.

I am restless if I am wrong before God. Then I take the Qur'an and I open the origin. My eyes immediately rested on verse 227 of the letter: 26 (Ash-Shu'arā ') "except for those (poets) who have faith and do good deeds and say a lot about Allah and get victory after suffering from wrongdoing. And those who the tyrant will know where they will return. "After reading that, I was thrilled and motivated to be more responsible before God (Nashita)

The seventh theme: Maintaining good relationship with God through worship

Muslim novelists express the worship they do has an impact in getting ideas easily in the process of writing a novel. The purpose of worship is to getting closer to God. Praying is an instrument that facilitates ideas.

Does worshiping Allah and daily behavior make it easier for you to get ideas? Answer: Yes. Favorite worship is prayer... (Efy Sofia).

I always pray, only writings that are in accordance with His pleasure, which only benefit the good, and far from bad sins, who will be born to fetch his destiny (Nashita)

I do not know whether worship is directly correlated with the ease of getting ideas, but I am sure that when we draw closer to Allah then all our efforts in good will be facilitated (Fakhrisina)

The eighth theme: Maintain good relations with fellow human beings

A good relationship with fellow human beings makes it easier for Muslim novelists to write their novels.

I think my good relationship with others (an implementation of morals) helped me a lot in the creative writing process. For example, when I need a resource for researching my novel, I often don't find any significant difficulties because I have a good relationship with the resourceful person, (Fakhrisina)

\section{The ninth theme: Writing as part of sharing}

Muslim novelists realize that the main motivation of writers is to share their thoughts with their readers.

The leverage of writing for me is the pleasure and happiness when I can share them to my readers. I am happy and proud when I can share writings that are useful for readers. That feeling continues to make me want to write with my eyes (Nashita).

I always pray, only writings that are in accordance with His pleasure, which only benefit the good, and far from bad sins, who will be born to fetch his destiny. Insya Allah (Nashita).

\section{The tenth theme: Writing as part of da'wah (spreading Islamic values)}

For Muslim novelists, the novel they write is intended to convey the truth and reject damage.
The idea will arise if there is something out of line (both human and natural environment) that is not in accordance with manners / morals. This imbalance or discrepancy must then be conveyed to the reader (Redy)

\section{DISCUSSIONS}

The results show that Muslim novelists experiencing various activities during their creative process that are unique in term of their relevance to the faith of Islam. These experiences can be categorized into three dimensions, i.e. practical dimension, mental-cognitive (intellectual) dimension, and spiritual dimension.

The most fundamental creative process in writing is to produce the ideas as good as possible, either for the content of writing or how to write novel. The main requirement to do the creative process is to understand the problem deeply. The way in the Muslim novelists to increase the knowledge about what they interested through reading, either with books, novels, news, other reading sources, and watching movies. In other words, their main activity is always trying to deliberately increase the knowledge of the problem that they are interested. The finding is in accordance to Nashori [8] on Muslim writers and in accordance to Liswarman and Nashori [9] on Muslim calligraphers.

Another thing that can also be seen as the way to create creativity in writing is by observing and getting involved directly. This is done by involve directly to the activity that they are interested, sensitive with the environment, and do good to others. Observation and doing good thing to others make the Muslim novelists more able to live with the object that will be written and deeply understanding with their ideas. The finding is in accordance to Nashori [8] on Muslim writers and in accordance to Liswarman and Nashori [9] on Muslim calligraphers

The findings which were different from previous findings are the effort to create an atmosphere that supports the writing of the novel. Muslim novelists choose a calm and quiet atmosphere. This atmosphere makes it easy for them to express their various inspirations.

The activity of reading and watching, doing good things to others, and creating supportive atmosphere has a great impact on the crative process of Muslim novelists. It can be said that these two activities are done intensively will make the Muslim novelists gain a way to generate the creative ideas.

One of the most important findings of this research is the awareness of Muslim novelists that the ideas come from God. Knowledge, ideas, motivation for writing their novels comes from God. Muslim novelists also realize that what they write in their novels must also be held accountable to Allah.

What we learn from western textbooks of creativity, imply that those dimensions are independent to each other. For example, in the early 20th century, creativity is thought to be mystical phenomenon saying that some mystical forces intervene a person and make the person create something novel. The famous English writer, Rudyard Kipling, once explained about the process of his creative works, "My Daemon was with me in the Jungle Books ... When your Daemon is in charge, do not think consciously. Drift, wait, and obey!". This spiritual view is then contrasted with scientific approach, in the sense that if there is some mystical 
or spiritual phenomenon on creative process then there is no place for scientific psychology to participate in the study of creativity. Sternberg [11] illustrates the issue with the following statement, "We believe that it has been hard for the scientific approach to shake the deep-seated view of some people that, somehow, scientific psychologists are treading where they should not."

The case is not the same in the Muslim world, where spirituality is always a part of the process of creation. Since the beginning of Islam Civilization, there was a consistent phenomenon happened within the Muslim scholar such as Ibnu Sina (Avicenna), and others. There is no doubt about the quality and novelty of the works of early Muslim scholars. Even the western civilization nowadays still recognizes the works of Ibnu Sina, such as The Cannon of Medicine. If we read the history, we will find that the creative process of early Muslim writers was always multidimensional. They were not just creative writers, but also devoted Muslims, and good persons. They always maintain good conduct and never claimed their creation as their individual accomplishment without any help from Allah, as the supreme spiritual being $[12,13]$.

One of the important findings in this study is that Muslim novelists consider that writing as part of sharing and preaching. The novels they produce contain stories that can inspire readers to become good personalities and provide optimal benefits. They seem to have felt what psychologists call the emphatic joy hypothesis, which is a feeling of pleasure when they know that it has had a positive influence by helping others [14].. This is evident from the activities of writing novels that they do continuously. Furthermore, they also make a novel event to convey the truth. By presenting a variety of good behavior, bad behavior, and the imbalance that occurs between the two in their novels, the novel's authors hope that there will be a new awareness or guidance to the reader.

\section{CONCLUSION}

The results of current study confirm the characteristics of the creative process of Muslim novelists, that is multidimensional which consist of three dimension, i.e. spiritual, practical, and intellectual. The creative process of Indonesian Muslim novelists consists of: (i) awareness of God as a source of ideas, (ii) reading and watching activities, (iii) observing various human behavior and natural phenomena, (iv) contemplating, (v) creating an atmosphere that support the writing of the novel, (vi) realize that the novel will be accountable to God, (vii) maintain good relations with God through worship, (viii) maintain good relations with fellow human beings, (ix) write as part of sharing, and ( $\mathrm{x}$ ) write as part of da'wahThe preferred spelling of the word "acknowledgment" in America is without an "e" after the "g". Avoid the stilted expression "one of us (R. B. G.) thanks ...". Instead, try "R. B. G. thanks...". Put sponsor acknowledgments in the unnumbered footnote on the first page.

\section{REFERENCES}

[1] Nashori, F. \& Mucharam, R. D. (2002). Develoing creativity (Mengembangkan kreativitas). Yogyakarta: Menara Kudus Jogja.

[2] Oppezzo, M. \& Schwartz, D.L. (2013). Give your ideas some legs: The positive effect of walking on creative thinking. Journal of Experimental Psychology: Learning, Memory, and Cognition, 40 (4), 1142-1152. http://dx.doi.org/10.1037/a0036577.
[3] Ritter, S.M. \& Dijksterhuis, A. (2014). Creativity-the unconscious foundations of the incubation period. Front Hum Neurosci, 8, 215.

[4] Munandar, S.C.U. (2009). Pengembangan kreativitas anak berbakat. Jakarta: PT Rineka Cipta dan Dep. Pendidikan dan Kebudayaan.

[5] Roberts, T. B. (Ed.). (1975). Four Psychologies applied to education: Freudian, behavioral, humanistic, transpersonal. New York: Wiley and Sons.

[6] Eneste, P. (2009). Creative process: Why and how I write? (Proses kreatif: Mengapa dan bagaimana saya mengarang). Jakarta: Kepustakaan Populer Gramedia (KPG).

[7] Csikszentmihalyi, M. (2013). Creativity: Flow and the psychology of discovery and invention. New York: Harper Collins Publishers.

[8] Nashori, H.F. (2004). Proses kreatif penulis muslim Indonesia: Perspektif psikologi islami. Jurnal Pemikiran dan Penelitian Psikologi PSIKOLOGIKA, 9(1), 5-20

[9] Liswarman, N.G. \& Nashori, H.F. (2010). Proses kreatif pelukis kaligrafi Islam: Sebuah penelitian kualitatif. Proyeksi, 5(1), 1-16.

[10] Sugiyono. (2015). Metode penelitian pendidikan: Pendekatan kuantitatif dan kualitatif R\&D. Bandung: Alfabeta.

[11] Sternberg, R. J (editor). (2014). Handbook of creativity. Cambridge: Cambridge University Press.

[12] Arsyad, M.N. (1995). Muslim scientist along history: From Jabir until Abdus Salam (Ilmuwan Muslim Sepanjang Sejarah: Dari Jabir hingga Abdus Salam). Bandung: Mizan Publisher.

[13] Nashori, H.F. (2017). Agenda of islamic psychology (Agenda psikologi islam). Yogyakarta: Pustaka Pelajar.

[14] Batson, C.D., Batson, J.G., Slingsby, J.K., Harrell, K.L., Peekna, H.M., \& Todd, R.M. (1991). Emphatic joy and the empathy-altruism hypothesis. Journal of Personality and Social Psychology, 61(3), 413426. 